\title{
ANALISIS PENERAPAN HAZARD ANALYSIS CRITICAL CONTROL POINT (HACCP) PADA PENGOLAHAN MAKANAN DI MAINKITCHEN HYATT REGENCY YOGYAKARTA
}

\author{
Hermawan Prasetyanto \\ NIDN 0516057102 \\ Email: hermawan@ampta.ac.id \\ Sekolah Tinggi Pariwisata AMPTA Yogyakarta \\ Yosephine Bayu Ratri \\ Sekolah Tinggi Pariwisata AMPTA Yogyakarta
}

\begin{abstract}
ABSTRAC
This study aimed to analyze the application of the principles of Hazard Analysis Critical Control Points (HACCP) in food processing in the Hyatt Regency Yogyakarta main kitchen as an effort to ensure food security. The design of this study is qualitative research conducted at the Hyatt Regency Yogyakarta in May 2017. Data collection uses in-depth interviews, observations, and document studies. From the results of interviews and observations it is known that the determination of hazard identification is in accordance with HACCP provisions, the determination of critical control points (CCP) has been focused on activities that are considered critical can cause danger, have set critical limits at each critical control point established, monitoring implementation has been focused at each critical control point and monitored by the Hygiene Officer 2 (two) times per day, has established corrective actions for each critical control point that is not able to reach the critical limit, verification actions have been carried out and have been scheduled, HACCP design documentation activities and other documents have been do. The results of this study are that the application of the principles of HACCP in food processing in main kitchen has been well implemented in accordance with the standards so that it can be said that the processing of food in the Hyatt Regency Yogyakarta main kitchen has guaranteed food security for guests.
\end{abstract}

Keyword: HACCP, food security, food processing, playing kitchen.

\section{PENDAHULUAN}

Hotel merupakan suatu industri atau usaha jasa yang dikelola secara komersil (Hermawan dkk., 2018). Komersial berarti disediakan bagi setiap orang untuk memperoleh pelayanan penginapan berikut makan dan minum (2008, 27). Hotel dalam menyediakan jasa yang biasa juga disebut sebagai 'product' kepada tamu, memiliki tujuan untuk memperoleh keuntungan. Pendapatan utama sebuah hotel adalah dari penjualan kamarnya, dan yang kedua adalah dari penjualan makanan dan minuman, baik itu di restoran maupun dalam pengadaan sebuah event.

Seiring dengan kemajuan zaman, makanan dan minuman yang lezat saja tak cukup bagi tamu. Makanan dan minuman yang memenuhi kebutuhan gizi serta aman dikonsumsi merupakan hal yang diutamakan bagi tamu dewasa ini. Namun, masalah keamanan pangan di Indonesia belum menjadi perhatian utama. Padahal lebih dari $90 \%$ penyakit pada manusia terkait faktor konsumsi makanan yang disebabkan oleh kontaminasi mikrobiologi, seperti bakteri, parasit, protozoa dan virus. Kontaminasi mikrobiologi tersebutlah yang akan menyebabkan tifus, disentri, hepatitis A ataupun keracunan makanan. Sebagai upaya untuk mengatasi masalah ini dan memenuhi kebutuhan tamu akan keamanan pangan, restoran hotel memiliki prosedural yang benar dalam menangani makanan dan minuman. Prosedural ini dimulai dari pembelian, penerimaan, penyimpanan, pengolahan, dan sampai pada penyajian makanan dan minuman kepada tamu. Setiap bahan makanan dapat menjadi penyebab masalah kesehatan. Bahan makanan dapat 
terkontaminasi sejak dari proses awal, pengemasan, pengiriman, penerimaan, penyimpanan, sampai pada sesaat sebelum dimakan. Kemungkinan terjadinya kontaminasi pada bahan makanan mendorong setiap negara untuk melindungi konsumen / tamu dengan mengeluarkan kebijakan berupa peraturan-peraturan dan standar mutu.

Pengawasan pangan yang mengandalkan pada uji produk akhir tidak dapat mengimbangi kemajuan yang pesat dalam industri pangan, dan tidak dapat menjamin keamanan makanan yang beredar di pasaran. Pendekatan tradisionil yang selama ini dilakukan dapat dianggap telah gagal untuk mengatasi masalah tersebut. Oleh karena itu, sebuah hotel menerapkan sistem Hazard Analysis Critical Control Point (HACCP) untuk menjamin mutu dan kemanan pangan bagi tamu. Pada saat ini, Hazard Analysis Critical Control Point (HACCP) dianggap sebagai pendekatan ilmiah yang paling efektif dalam mengendalikan bahaya-bahaya mikrobiologis, kimia, dan fisik yang ada dalam rantai pangan. HACPP dinilai mampu memberikan jaminan keamanan pangan yang lebih baik ketimbang sistem pengawasan mutu konvensional. HACCP dijelaskan oleh Sugiono sebagai peranti atau sarana untuk melakukan penilaian terhadap suatu bahya kemudian menetapkan sistem pengendalian bahaya tersebut yang memfokuskan pada pencegahan bahaya yang teridentifikasi tersebut, dan bukan mengandalkan sebagian besar pada pengujian terhadap produk akhir (2013:36). Dengan kata lain, sistem ini menitik beratkan pada pengawasan dari awal bahan pangan tersebut diproduksi oleh vendor, diterima oleh hotel, disimpan, diolah, dan sesaat sebelum makanan dikonsumsi oleh tamu sebagai tindakan pencegahan agar makanan tak terkontaminasi bahaya (Hazard Analysis Critical Control Point).

Kitchen dalam sebuah hotel bertugas untuk mengolah bahan makanan menjadi makanan yang siap dimakan. Menurut Syamsul Rijal dapur adalah suatu ruangan khusus yang diperuntukan sebagai tempat untuk memasak makanan (2000:14). Analisis
HACCP di kitchen penting dilakukan mengingat kitchen merupakan tempat terakhir makanan diolah dan diawasi. Penerapan HACCP dalam kitchen bertujuan agar makanan tidak terkontaminasi dan dapat dipastikan aman untuk dikonsumsi oleh tamu. Kitchen merupakan tempat yang kompleks dan sangat rawan terhadap pencemaran makanan karena tempatnya yang besar, peralatannya yang beragam, dan banyaknya pekerja yang bekerja pada begian kitchen. HACCP pada kitchen diterapkan secara menyeluruh, mulai dari kebersihan dan kesehatan personal, kebersihan area kerja serta peralatan masak, dan tentu pada pengolahan bahan makanan sampai siap disantap oleh tamu. Namun, keberhasilan kitchen dalam menjamin keamanan pangan tidak terlepas dari kerjasama bagian lain seperti, bagian Receiving sebagai filter awal dalam proses penerimaan bahanan makanan sesuai standar HACCP, bagian Store, bagian Engineering dalam me-maintenance walk-in chiller/freezer, serta bagian FB Service dalam menyajikan makanan.

Dengan permasalahan tersebut, maka penulis ingin meneliti bagaimana penerapan Hazard Analysis Critical Control Point (HACCP) pada pengolahan bahan makanan di main kitchen Hyatt Regency Yogyakarta dengan judul "Analisis Penerapan Hazard Analysis Critical Control Point (HACCP) Pada Pengolahan Makanan Di Main Kitchen Hyatt Regency Yogyakarta.”

\section{LITERATUR REVIEW}

\section{Hazard Analysis Critical Control Point (HACCP)}

Pangan bermutu dan aman untuk memenuhi kebutuhan gizi dan kesehatan merupakan hak semua orang. Produsen bersama-sama dengan pemerintah wajib melakukan segala upaya untuk menghasilkan pangan bermutu yang aman secara berkesinambungan. Saat ini HACCP dianggap sebagai pendekatan ilmiah yang paling efektif dalam mengendalikan bahayabahaya mikrobiologi, kimia dan fisik yang ada di dalam rantai pangan. HACCP dinilai mampu memberikan jaminan keamanan 
pangan yang lebih baik ketimbang sistem pengawasan mutu konvensional.

Hazard Analysis Critical Control Point atau disingkat HACCP adalah suatu pendekatan ilmiah yang digunakan untuk mengelola bahaya keamanan pangan untuk menghasilkan pangan yang aman (Ratih Dewanti-Haryono. 2013, 4).

Menurut $\underline{\mathrm{WHO}}$, Analisis Bahaya dan Pengendalian Titik Kritis (Hazard Analysis and Critical Control Points, HACCP) didefinisikan sebagai suatu pendekatan ilmiah, rasional, dan sistematik untuk mengidentifikasi, menilai, dan mengendalikan bahaya. Pada awalnya, prinsip HACCP dibuat untuk keamanan bahaya pangan, namun sistem ini akhirnya dapat diaplikasikan lebih luas dan mencakup industri lainnya. Aplikasi HACCP, terutama yang diperuntukkan bagi pangan, dilaksanakan berdasarkan beberapa pedoman, yaitu prinsip umum kebersihan pangan Codex, Codex yang sesuai dengan kode praktik, dan undang-undang keamanan pangan yang sesuai.

Dikutip dari situs Department of Food Science and Technology - IPB, HACCP adalah suatu sistem kontrol dalam upaya pencegahan terjadinya masalah yang didasarkan atas identifikasi titik-titik kritis di dalam tahap penanganan dan proses produksi. HACCP merupakan salah satu bentuk manajemen resiko yang dikembangkan untuk menjamin keamanan pangan dengan pendekatan pencegahan (preventive) yang dianggap dapat memberikan jaminan dalam menghasilkan makanan yang aman bagi konsumen.

Sedangkan Sugiono menjelaskan HACCP merupakan peranti atau sarana untuk melakukan penilaian terhadap suatu bahaya kemudian menetapkan sistem pengendalian bahaya tersebut memfokuskan pada pencegahan bahaya yang teridentifikasi tersebut, bukan mengandalkan sebagian besar pada pengujian terhadap produk akhir (2013, 36). Pendekatan yang terdiri dari 7 prinsip ini diwujudkan dalam satu rencana HACCP (HACCP Plan) yang diimplementasikan selama proses produksi untuk mencegah masuknya bahaya dalam setiap tahap pengolahan serta menekan peningkatan bahaya yang mungkin terjadi selama pangan diolah, sejak dari bahan baku, produk jadi dan sampai pada tangan konsumen.

Standar HACCP yang berasal dari naskah CAC-RCP 1-1969, Rev. 3 (1997)Recommended Internationl Code of PracticeGeneral Principle of Food Hygiene-Annex: Hazard Analysis Critical Control Point (HACCP)System and Guidelined for its Application yang kemudian ditetapkan menjadi SNI 01-4852-1998, Sistem analisis dan pengendalian titik kritis serta pedoman penerapannya, kemudian dimutakhirkan oleh Rev. 4 (2003) dan diadopsi penuh oleh Badan Standarisasi Nasional (BSN) sebagai SNI CAC/RCP 1:2011, Rekomendasi Nasional Kode Praktis-Prinsip umum higiene pangan, yang merevisi SNI sebelumnya.

Sistem HACCP terdiri atas 7 prinsip, sebagimana yang dijelaskan oleh Sugiono (2013:37), antara lain:

1) Melaksanakan analisa bahaya

Analisis bahaya adalah pekerjaan paling krusial yang memerlukan pengetahuan yang mendalam mengenai produk pangan yang dihasilkan, ingredien yang digunakan, teknologi dan proses yang diaplikasikan, dan berbagai prosedur yang diterapkan.

2) Menentukan Titik Kendali Kritis

Critical Control Point (CCP) didefinisikan sebagai suatu titik atau prosedur dalam tahap-tahap pengolahan pengan yang dapat menghasilkan produk yang membahayakan kesehatan manusia jika tidak dikendalikan dengan tepat. CCP dapat berupa tahap proses, formulasi atau bahan baku yang mengandung bahaya yang tidak dapat dikendalikan pada tahap-tahap pengolahan yang ada.

\section{3) Menetapkan batas kritis}

Batas kritis atau critical limit (CL) adalah satu atau lebih batas parameter yang harus dipenuhi untuk tiap CCP. Batas tersebut memisahkan antara apa yang dianggap aman dengan yang tidak aman berdasarkan bahaya mikrobiologi, kimia, dan fisik. Karena batas kritis ini akan dipantau secara real-time, maka batas harus dipilih berdasarkan suatu 
kriteria yang dapat diukur atau diobservasi dengan mudah dan cepat.

4) Menetapkan suatu sistem pemantauan pengendalian $\mathrm{CCP}$

Pemantauan atau monitoring adalah seperangkat pengamatan terjadwal yang diimplementasikan pada CCP untuk menjamin bahwa batas kritis-nya terpenuhi. Jika batas kritis suatu CCP telah ditetapkan, maka pemantauan terhadap batas kritis tersebut harus diimplementasikan. Prosedur pemantauan mencakup apa yang akan dipantau, siapa yang ditugaskan memantau, kapan pemantauan dilakukan, di mana pemantauan dilakukan, dan bagaimana suatu pemantauan dilakukan.

5) Menetapkan tindakan perbaikan yang dilakukan jika hasil pemantauan menunjukan bahwa suatu CCP tertentu tidak dalam kendali

Apabila pada saat monitoring ditemukan bahwa CL tidak terpenuhi, maka perlu direncanakan suatu tindakan koreksi untuk memberikan jaminan bahwa produk pangan yang dihasilkan aman. Tindakan koreksi yang dimaksud ada 2 macam yakni tindakan yang bersifat segera (correction) dan yang bersifat pencegahan penyimpangan (deviation control).

6) Menetapkan prosedur verfikasi untuk memastikan bahwa sistem HACCP bekerja secara efektif.

Verifikasi dalam penyusunan rencana HACCP addalah serangkaian kegiatan yang dilakukan untuk menjamin bawha rencana HACCP tersebut dapat mengendalikan keamanan pangan secara efektif, telah disusun sesuai dengan ketujuh prinsip yang ada, serta telah diimplementasikan sesuai dengan rencana HACCP yang disusun. Untuk menjamin bahwa rencana HACCP dapat mengendalikan keamanan pangan, maka dilakukan pengujian produk, kalibrasi alat, dan review terhadap hasil pemantauan. Untuk menjamin bahwa penyusunan rencana HACCP dan implementasinya telah sesuai dengan 7 prinsip HACCP, umumnya dilakukan audit.
7) Menetapkan dokumentasi mengenai seluruh prosedur dan rekaman yang sesuai dengan prinsip-prinsip ini dan penerapannya.

Dokumentasi atau pencatatan rekaman dalam suatu rencana HACCP adalah rekaman kegiatan penyusunan rencana HACCP dan implementasinya. Dokumen yang direkam setidaknya mencakup rencana HACCP yang telah disusun dan semua dokumen pendukungnya, rekaman hasil monitoring, dokumen tindakan koreksi, dan dokumen prosedur verifikasi.

Meskipun demikian, keberhasilan setiap sistem HACCP akan bergantung pada manajemen dan para karyawan yang mempunyai pengetahuan dan keterampilan yang sesuai dengan bidang HACCP. Oleh karena itu, palaksanaan pelatihan yang berkelanjutan diperlukan bagi seluruh tingkatan karyawan dan manajemen yang sesuai.

Sistem HACCP dapat diterapkan dengan 12 langkah, yaitu:

1) Pembentukan Tim HACCP

2) Deskripsi Produk

3) Identifikasi Maksud Penggunaan

4) Menyusun Diagram Alir

5) Konfirmasi Bagan Alir ke Lapangan

6) Daftar semua bahaya potensial yang terkait dengan setiap tahapan, lakukan analisa bahaya, dan pertimbangkan setiap tindakan untuk mengendalikan bahayabahaya yang teridentifikasi

7) Penentuan Titik Kendali Kritis

8) Menetapkan batas kritis untuk setiap CCP

9) Penetapan sistem pemantauan untuk setiap $\mathrm{CCP}$

10) Penetapan tindakan perbaikan

11) Penetapan prosedur verifikasi

12) Penetapan dokumentasi dan pemeliharaan rekaman

Pelatihan personel di industri, pemerintahan, dan perguruan tinggi tentang prinsip-prinsip dan penerapan HACCP, serta peningkatan kesadaran konsumen merupakan elemen yang penting dalam penerapan HACCP secara efektif. Untuk membantu mengembangkan bahan pelatihan tertentu yang mendukung rencana HACCP, sebaiknya dikembangkan instruksi kerja dan 
prosedur yang menentukan tugas personel pelaksana yang ditempatkan pada setiap CCP. Kerjasama antara produsen primer, industri, kelompok pedagang, organisasi konsumen serta pihak yang berwenang sangat penting

\section{Mutu dan Keamanan Pangan}

Makanan merupakan kebutuhan utama dalam kehidupan sehari-hari manusia. Bukan hanya makanan yang lezat dimakan saja namun makanan tersebut harus memiliki mutu dan aman dikonsumsi oleh tamu. Menurut PP Nomor 28 tahun 2004 pengertian mutu pangan adalah nilai yang ditentukan atas dasar kriteria kamanan pangan, kandungan gizi, dan standar perdagangan terhadap bahan makanan, makanan, dan minuman. Sedangkan yang dimaksud dengan keamanan pangan menurut Ratih Dewanti merupakan kondisi atau upaya untuk menyediakan pangan yang bebas atau terkendali dari bahaya-bahaya (hazard) yang dapat menimbulkan gangguan kesehatan pada manusia (2013:5). Bahaya dalam pangan dapat berasal dari bahan baku, air, peralatan, lingkungan termasuk hewan di sekitar sarana produksi pangan, serta manusia yang menanganinya.

Saat ini HACCP dianggap sebagai suatu pendekatan yang paling dapat memberikan jaminan dalam menghasilkan pangan yang bermutu dan aman. Akan tetapi, rencana HACCP hanya dapat dikembangkan dan diimplementasikan secara optimal apabila program pra-syarat dasar telah terpenuhi dan diimplementasikan dengan baik pula pada suatu industri pangan. Program pra-syarat dasar dan manajemen mutu dan keamanan pangan yang dimaksud di industri pangan umumnya terdiri dari GMP atau CPPB dan SSOP atau Prosedur Operasi Sanitasi Standar.

GMP (Good Manufacturing Practices) atau CPPB (Cara Produksi Pangan yang Baik)

GMP adalah prasyaratan dasar yang semestinya dipenuhi oleh suatu perusahaan yang ingin menghasilkan pangan yang bermutu dan aman secara konsisten. Persyaratan dalam GMP mencakup persyaratan untuk pekerja, bangunan dan fasilitas, peralatan, dan pengendalian proses. Persyaratan untuk pekerja bertujuan untuk menghindarkan kontaminasi oleh pekerja, khususnya kontaminasi bahaya mikrobiologi yang bisa berasal dari pekerja sendiri dan praktik-praktik yang salah serta bahaya fisik yakni perhiasan, barang personal yang mungkin dibawa oleh pekerja. Oleh karena itu persyaratan ini menetapkan program kebersihan, kesehatan pekerja, pelatihan dan pendidikan tentang sanitasi pekerja.

Persyaratan untuk bangunan dan fasilitas mencakup tata letak untuk meminimalkan kontaminasi silang atau kontaminasi ulang, rancangan pabrik, program pembersihan dan sanitasi bangunan, serta pemeliharaan lingkungan. Persyaratan untuk peralatan juga mencakup tata letak peralatan yang meminimalkan kontaminasi, rancangan peralatan yang mudah dijangkau dan mudah dibersihkan serta persyaratan tentang bahan peralatan yang diizinkan, dan persyaratan pembersihan serta sanitasi. Persyaratan tentang pengendalian proses mencakup prosedur penanganan bahan baku, pemeliharaan, pengolahan, penyimpanan, pengendalian hama, penanganan limbah, dan sebagainya.

SSOP merupakan dokumen untuk tiaptiap aspek yang berisi kebijakan tentang tiap aspek, prosedur atau tahapan yang diperlukan, rujukan yang digunakan, tindakan koreksi yang harus dilakukan serta penanggungjawabnya. Food and Drug Administration (BPOM) mengusulkan 8 aspek atau kunci SSOP yang harus dibuat prosedurnya yaitu:

1) Keamanan air

2) Kebersihan permukaan yang kontak dengan pangan

3) Fasilitas sanitasi

4) Mencegah kontaminasi silang

5) Mencegah adulteration

6) Pelabelan senyawa toksik

7) Kesehatan pekerja, dan

8) Pengendalian hama

\section{Jenis Bahaya dalam Pangan}

Bahaya dalam pangan dapat dikategorikan menjadi bahaya biologi (tepatnya 
mikrobiologi), bahaya kimia, dan bahaya fisik.

Bahaya biologi yang utama adalah mikroorganisme yaitu makluk hidup berukuran sangat kecil yang tidak dapat dilihat oleh mata telanjang karena ukurannya yang sangat kecil (Ratih Dewanti, 20013:7). Beberapa jeenis mikroorganisme dalam pangan bersifat patogen, artinya dapat menyebabkan penyakit apabila pangan tersebut dikonsumsi. Bahaya mikrobiologi pada pangan terdiri dari virus, bakteri, protozoa, dan parasit. Di antara keempat golongan bahaya biologi di atas, bakteri adalah kelompok yang paling banyak dilaporkan dan diketahui modusnya dalam menyebabkan penyakit melalui pangan. Meskipun demikian, perkembangan teknologi deteksi telah menempatkan virus sebagai penyebab terbesar penyakit bawaan pangan (foodborne illness atau foodborne diseases) di Amerika Serikat dalam beberapa tahun terakhir. Ada 6 faktor yang mempengaruhi pertumbuhan mikroorganisme, yaitu food (makanan), acidity (keasaman), time (waktu), temperature (suhu), oxygen, dan moisture (aktifitas air). Atau yang lebih dikenal dengan istilah FATTOM.

\section{1) $\mathrm{F}$ : Food}

Mikroba membutuhkan nutrisi seperti protein dan karbohidrat, misalnya pada daging, dairy product, ikan dan hasil laut lainnya, telur.

\section{2) A : Acidity}

Hampir semua mikroba tumbuh pada tingkat $\mathrm{pH}$ yang berbeda. Sebagian besar mikroba lebih senang tumbuh pada kondisi netral $\mathrm{pH}$ 4,6 - 7,5. Pada $\mathrm{pH}$ dibawah 4,6 dan di atas 7,5 bakteri tidak dapat tumbuh dengan baik.

\section{3) $\mathrm{T}$ : Temperature}

Suhu merupakan faktor fisika yang sangat penting pengaruhnya terhadap pertumbuhan dan kegiatan mikroba. Hampir semua mikroba dapat hidup pada suhu antara $8^{\circ} \mathrm{C}$ $60^{\circ} \mathrm{C}$. Suhu dapat mempengaruhi kecepatan pertumbuhan, konsentrasi sel, kebutuhan nutrisi, dan komposisi sel.

4) $\mathrm{T}$ : Time

Mikroba membutuhkan waktu untuk tumbuh rata-rata 20 menit untuk membelah diri.
Makanan yang terkontaminasi, apabila dibiarkan pada suhu nyaman bakteri berkembang selama 4 jam maka sudah cukup untuk membuat makanan tersebut menjadi berbahaya. Hubungan antara suhu dengan waktu sangat penting dalam penanganan pangan.

\section{5) $O$ : Oxygen}

Setiap makluk hidup membutuhkan oksigen untuk hidup dan berkembang, begitu pula dengan bakteri. Pertumbuhan bakteri dapat dicegah dengan menghilangkan oksigen disekitar produk dengan sistem vaccuuming.

\section{6) $\mathrm{M}$ : Moisture}

Ketersediaan air menjadi syarat mutlak bagi pertumbuhan mikroorganisme. Hampir semua mikroba dapat tumbuh pada media dengan $\mathrm{a}_{w}$ di atras 0.85 .

Dengan adanya keenam faktor tersebut, mikroorganisme penyebab bahaya biologi dapat berkembang dengan baik dan dapat mengakibatkan gangguan kesehatan

\section{Penelitian Terdahulu}

Ada beberapa hasil penelitian terdahulu yang relevan dengan topik penelitian Analisis penerapan Hazard Analysis Critical Control Point (HACCP) di main kitchen Hyatt Regency Yogyakarta.

Adapun hasil penelitian terdahulu yang pernah dilakukan sebelumnya dengan tema mengenai Hazard Analysis Critical Control Point, yaitu:

Woroningrum Merdekawati (2001) dengan penelitiannya "Penerapan Hazard Analysis And Critical Control Point (Haccp) Terhadap Mutu Akhir Produk Jenang Ayu Di Industri Rumah Tangga Ny. Parto Mihardjo, Cawas, Kabupaten Klaten." Jenis penelitian adalah kuasi eksperimental dengan desain penelitian one group prevalensi test-post test design. Pengumpulan data dilakukan dengan observasi yakni pengamatan langsung mulai dari proses pengolahan sampai penyimpanan dan wawancara mendalam dilakukan pada produsen jenang dengan metode Tanya jawab. Analisa dilakukan secara statistik deskriptif dan analitik dengan Cochran test dan paired test. Hasil penelitian menunjukkan ada beberapa tahap produksi produsen melaksanakan cara emproduksi 
makanan yang baik (Good Manufacturing Product/ GMP), yang semua tahap dicatat dan didokumentasikan dalam table. Pengamatan mutu fisik dan citarasa menunjukkan tidak berbeda jauh, kecuali pada sampel dengan penyimpanan satu minggu dan tanpa HACCP yakni jenang ayu berubah menjadi agak tengik dan berjamur. Pengujian kedua dilakukan selang 3 hari kemudian, sampel yang mendapat perlkuan HACCP dan tidak disimpan mengalami degradasi paling rendah $(10,01 \mathrm{mg} / \mathrm{l} / \mathrm{g}$ sampel), sedangkan sampel tanpa penerapan HACCP dan disimpan satu minggu mengalami degradasi paling tinggi $(84,19$ $\mathrm{mg} / \mathrm{l} / \mathrm{g}$ sampel). Dengan Cochran test dan paired test diketahui adaperbedaan yang signifikan ant produk sebelum penerapan HACCP dengan setelah penerapan HACCP. Kesimpulan penelitian adalah produsen belum sepenuhnya melaksanakan cara memproduksi dengan baik.

Rina Febriana (2006) dalam penelitiannya "Penerapan Hazard Analysis Critical Control Point (HACCP) dalam Penyelenggaraan Warung Makan di Universitas Negeri Jakarta". Secara operasional penelitian ini bertujuan untuk mengetahui tingkat penerapan Hazard Analysis Critical Control Point (HACCP) pada warung makan kampus di lingkungan Kampus A Universitas Negeri Jakarta yang meliputi komponen penanganan bahan mentah, pemilihan bahan, persiapan, pengolahan, dan penyajian makanan. Penelitian menggunakan metode survey untuk mengetahui tingkat penerapan HACCP pada warung makan kampus. Lokasi penelitian ini di sekitar Kampus A Universitas Negeri Jakarta dengan 25 responden pemilik warung makan kampus. Penelitian dilakukan pada bulan Juli Oktober 2006. Hasil penelitian menunjukan bahwa penerapan HACCP pada warung makan kampus menunjukan data penanganan bahan mentah $96,15 \%$, pemilihan bahan $95 \%$, persiapan $94,25 \%$, pengolahan $99 \%$, dan penyajian $91,5 \%$. Secara umum rata-rata penerapan HACCP pada warung makan kampus di lingkungan Kampus A Universitas
Negeri Jakarta tergolong tinggi dengan tingkat penerapan rata-rata $95 \%$.

Nyoman Sutresni (2015) dengan penelitiannya "Penerapan Hazard Analysis Critical Control Point (HACCP) Pada Proses Pengolahan Produk Ikan Tuna Beku di Unit Pengolahan Ikan Pelabuhan Benoa - Bali”. Penelitian ini dilakukan dengan metode cross sectional. Untuk mengetahui tingkat penerapan kelayakan dasar (GMP dan SSOP) serta tingkat penerapan HACCP adalah berdasarkan pada penyimpangan minor, mayor, serius, dan kritis. Penentuan strategi penerapan HACCP dengan menggunakan matriks analisis SWOT. Hasil penelitian menunjukkan bahwa tingkat penerapan kelayakan dasar dan tingkat penerapan HACCP pada 15 unit pengolahan ikan yaitu, terdapat 9 unit pengolahan ikan dengan klasifikasi tingkat A (baik sekali) dan 6 unit pengolahan ikan dengan klasifikasi tingkat B (baik). Strategi penerapan HACCP pada proses pengolahan ikan tuna beku di unit pengolahan ikan Pelabuhan Benoa - bali yaitu strategi untuk meningkatkan jaminan mutu dan keamanan pangan serta kualitas lingkungan di lokasi penelitian. Hasil penelitian ini dapat disimpulkan bahwa unit pengolahan ikan pada lokasi penelitian di Pelabuhan Benoa telah menerapkan kelayakan dasar (GMP dan SSOP) serta penerapan HACCP dengan baik.

\section{METODE PENELITIAN}

Berdasarkan pada masalah yang diangkat dalam penelitian ini maka jenis penelitian yang digunakan adalah deskriptif kualitatif. Peneliti mengambil lokasi di Hyatt Regency Yogyakarta, Sariharjo, Ngaglik, Sleman, D. I. Yogyakarta. Melakukan wawancara dan pengamatan langsung yang akan dilakukan pada Mei 2017.

Teknik pengambilan sampel sumber data, yang dipakai adalah teknik cuplikan. Teknik cuplikan pada awalnya jumlah sedikit, lamalama menjadi besar. Hal ini dilakukan karena data yang diterima atau dihasilkan dari sumber data yang sedikit belum lengkap, maka peneliti mencari orang lain yang dapat digunakan sebagai sumber data untuk 
melengkapi data yang diberikan sebelumnya. Dalam penelitian yang akan dilaksanakan ini teknik cuplikan diperoleh dari HR, tim HACCP, chef, cook, receiving, engineering staff, dan steward yang bekerja diHyatt Regency Yogyakarta. Data yang diperoleh dari beberapa informan tersebut diambil berdasarkan pertanyaan yang daiajukan peneliti. Setiap penerapan HACCP dalam main kitchen Hyatt Regency Yogyakarta bertujuan untuk mengendalikan bahaya (hazard). Sehingga setiap pertanyaan yang diajukan akan mengacu kepada upaya pengendalian bahaya di main kitchen Hyatt Regency Yogyakarta. Bahaya-bahaya yang mungkin ada dalam main kitchen Hyatt Regency Yogyakarta

Penelitian ini menggunakan tiga macam trianggulasi, yang pertama, trianggulasi sumber data yang berupa informasi dari tempat, peristiwa, dan dokumen serta arsip yang memuat catatan berkaitan dengan data yang dimaksud. Yang kedua, trianggulasi teknik atau metode pengumpulan data yang berasal dari wawancara, observasi, dan dokumen. Ketiga, trianggulasi pengumpulan data merupakan kapan dilaksanakannya trianggulasi atau metode pengumpulan data.

Teknik analisis data yang digunakan dalam penelitian ini adalah analisis interaktif. Miles dan Huberman mengemukakan bahwa aktivitas dalam analisis data kualitatif dilakukan secara interaktif dan terus menerus sampai tuntas, sehingga datanya jenuh. Jenuh artinya tidak ada data lagi yang baru, semua data telah diperoleh peneliti (1992:15). Analisis data kualitatif menuurut Miles dan Huberman (1992:15-19) terdiri dari tiga alur, yaitu:

1. Reduksi data, yaitu sebagai proses seleksi, pemfokusan, pengabstrakan, transformasi data kasar yang muncul dari catatan-catatan tertulis di Hyatt Regency Yogyakarta, dan diteruskan pada waktu pengumpulan data. Dengan demikian reduksi data sudah dimulai sejak peneliti memfokuskan wilayah penelitian. Selama proses pengumpulan data berlangsung, terjadilah tahapan reduksi selanjutnya. Proses pengumpulan data dilakukan dengan melakukan observasi, wawancara, dan olah dokumen di main kitchen Hyatt Regency Yogyakarta. Reduksi data ini terus berlanjut sesudah penelitian lapangan, sampai laporan akhir lengkap tersusun,

2. Penyajian data, alur penting yang kedua dari kegiatan analisis adalah penyajian data. Miles dan Huberman membatasi suatu penyajian sebagai sekumpulan informasi tersusun yang memberi kemungkinan adanya penarikan kesimpulan dan pengambilan tindakan. Penyajian yang lebih baik merupakan suatu cara bagi analisis kualitatif yang valid. Penyajian yang dimaksud meliputi berbagai jenis matriks, grafik, jaringan, dan bagan. Semua dirancang guna menggabungkan informasi yang tersusun dalam suatu bentuk yang padu dan mudah diraih.

3. Penarikan Kesimpulan, kesimpulan awal yang dikemukakan masih bersifat sementara, dan akan berubah bila tidak ditemukan bukti-bukti yang kuat yang mendukung pada tahap pengumpulan data berikutnya. Namun apabila kesimpulan memang telah didukung oleh bukti-bukti yang valid dan konsisten saat peneliti kembali ke lapangan mengumpulkan data, maka kesimpulan yang dikemukakan merupakan kesimpulan yang kredibel. Kesimpulan ini diharapkan merupakan temuan baru yang sebelumnya belum pernah ada.

\section{HASIL DAN PEMBAHASAN Deskripsi Objek Penelitian}

Hyatt Regency Yogyakarta merupakan salah hotel berbintang 5 yang terletak di lingkar luar Yogyakarta, dapat ditempuh dari Bandara Adi Sucipto dalam waktu 20 menit dan 15 menit dari Malioboro atau pusat kota, tepatnya di Jalan Palagan Tentara Pelajar, Sariharjo, Ngaglik, Kabupaten Sleman, Daerah Istimewa Yogyakarta 05581. Hotel Hyatt berpusat di Chicago, Amerika dan mempunyai beberapa hotel yang tersebar di seluruh dunia, salah satunya Indonesia. Indonesia memiliki 5 Hotel Hyatt yang tersebar di berbagai wilayah seperti Grand Hyatt Jakarta, Hyatt Regency City Surabaya 
yang kini bernama Hotel Bumi Surabaya, Hyatt Regency Bandung atau Hotel Aryaduta Bandung, Grand Hyatt Bali Nusadua, Hotel Bali Hyatt Sanur Beach, dan Hyatt Regency Yogyakarta.

Hyatt Regency Yogyakarta meiliki total 269 kamar yang terdiri dari 209 Garden View Rooms, 51 Regency Club Rooms, 6 Junior Suites, 2 Executive Suites, 1 Presidential Suite.Berdiri di tengah kebun dan lapangan golf seluas 22 hektar dan menghdap langsung kepada gunung legendaris di Jawa Tengah, Gunung Merapi membuat Hyatt Regency Yogyakarta menjdadi hotel satu-satunya yang berkonsep alam di Yogyakarta. Apabila beruntung, tamu dapat menikmati pagi dengan pemandangan Sang Gunung Merapi tepat di depan mata tanpa harus keluar kamar.

Hyatt Regency Yogyakarta yang dimiliki oleh PT. Antilope Madju ini dibangun pada tahun 1997, tepatnya tanggal 17 Oktober. Design yang unik berkonsep Borobudur yang dimiliki oleh Hyatt Regency Yogyakarta dirancang oleh PT. Shimizu Lampiri Consultant. Tak heran apabila Hyatt Regency Yogyakarta pernah menyabet penghargaan sebagai hotel Hyatt terbaik kedua dari seluruh hotel Hyatt di dunia.

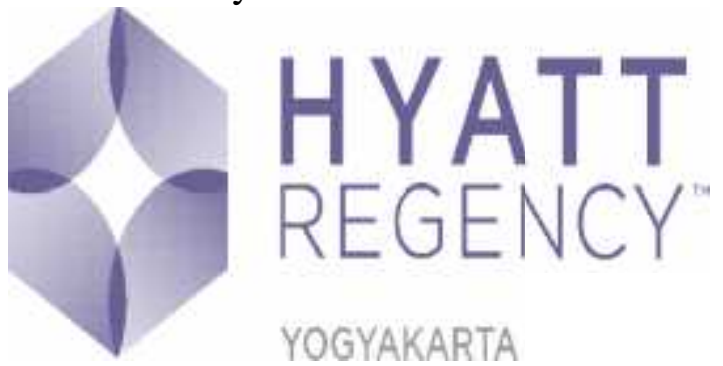

Gambar 1. Logo Hotel Hyatt

\section{Analisis Bahaya}

Berdasarkan SNI 01-4852-1998, diagram alir merupakan suatu gambaran yang sistematis dari urutan tahapan atau pelaksanaan pekerjaan yang dipergunakan dalam produksi atau dalam menghasilkan pangan tertentu.

Dari hasil wawancara dan observasi yang dilakukan peneliti, penyusunan bagan alir telah dilakukan untuk setiap makanan yang diproduksi. diagram alir di Hyatt dibedakan menjadi 2 (dua), yaitu diagram alir untuk cold process dan hot process. Diagram alir yang dimiliki Hyatt Regency Yogyakarta sudah lengkap dimulai dari proses penerimaan, penyimpanan, proses pengolahan makanan, pendistribusian, sampai penyajian makanan pada tamu.

Proses pengumpulan dan penilaian informasi mengenai bahaya dan keadaan sampai dapat terjadinya bahaya, untuk menentukan yang mana berdampak nyata terhadap keamanan pangan, dan harus ditangani dalam rencana HACCP (SNI 014852-1998).

Berdasarkan hasil wawancara dan observasi dokumen pengidentifikasian bahaya dan analisis risiko bahaya telah dilakukan di Hyatt Regency Yogyakarta. Identifikasi bahaya telah mencakup bahaya bilogi, kimia, dan bahaya fisik. Identifikasi bahaya yang dilakukan telah dimulai dari proses penerimaan bahan makanan, penyimpanan bahan makanan, proses pengolahan, proses pendistribusian, penyimpanan panas, pendinginan secara cepat, pemanasan ulang, pendistribusian, kontaminasi silang dari karyawan penjamah makanan, dan juga dari peralatan yang digunakan dalam kegiatan tersebut. Hyatt Regency Yogyakarta memiliki dokumentasi untuk seluruh identifikasi bahaya yang dilakukan.

Selain melakukan identifikasi bahaya, Hyatt Regency Yogyakarta juga telah menetapkan tindakan pencegahan dan pengendalian untuk setiap potensi bahaya yang telah diidentifikasi.

1) Identifikasi Bahaya Biologi

Pengidentifikasian bahaya biologi harus dapat mengidentifikasi bahaya bakteri, viruz, protozoa, cacing, parasit, dan bahaya biologi lainnya.

Untuk tindakan pencegahan dan pengendalian, Hyatt Regency Yogyakarta hanya menggunakan supplier bahan makanan yang sudah terdaftar, dan pihak Hyatt Regency Yogyakarta selalu mengadakan inspeksi mendadak ke tempat supplier untuk memastikan bahwa supplier menerapkan hygiene dan sanitasi pada proses pengolahan dan penyimpanan bahan makanan sebelum 
dikirim ke Hyatt Regency Yogyakarta. Pencegahan juga dilakukan pada saat proses penerimaan dengan mengamati tampilan bahan makanannya, tekstur, suhu bahan makanan serta kebersihan vehicle pengirim bahan makanan. Menyediakan air yang aman untuk dikonsumsi, serta memperhatikan kesehatan penjamah makanan dan personal hygiene-nya juga merupakan pencegahan kontaminasi bahaya mikrobiologi terhadap bahan makanan.

2) Identifikasi Bahaya Kimia

Dalam teori, bahaya kimia dalam pangan mencakup semua senyawa kimia yang ada dalam pangan yang dapat menyebabkan gangguan penyakit jika dikonsumsi dalam jumlah tertentu. Bahan kimia dalam pangan mungkin memasuki rantai pangan selama produksi dan pemanenan di ladang/ternak/tambak, penanganan, pengolahan maupun distribusinya.

Dari hasil wawancara dan observasi yang dilakukan penulis, Hyatt Regency Yogyakarta telah melaksanakan identifikasi bahaya kimia dengan baik. Tindakan pengendalian dan pencegahan yang dilakukan Hyatt Regency Yogyakarta adalah dengan memberikan food tag pada setiap makanan yang disajikan dan melakukan guest recognation agar pihak hotel lebih mengenal tamu yang memiliki alergi pada bahan makanan tertentu; selalu mencuci buah dan sayuran yang dimakan mentah dengan air mengalir serta air sanitasi untuk mencegah masih tersisanya pestisida dan obat yang menempel pada bahan makanan; pencucian peralatan selalu menggunakan detergen dan air sanitasi; tidak menggunakan wadah makan plastik dan melamin; tidak pernah menggunakan bahan kimia seperti formalin, boraks, dan rhodamin; dan selalu mengadakan sampling makanan ready to eat.

3) Identifikasi Bahaya Fisik

Dalam teori identifikasi beberapa bahaya fisik mencakup kontaminasi serangga, pecahan kaca, logam, batu, potongan kayu kecil, dan kontaminasi dari tenaga penjamah.

Tindakan pencegahan dan pengendalian yang dilakukan oleh Hyatt Regency Yogyakarta berdasarkan wawancara dan observasi adalah standar pengiriman bahan makanan yang harus bersih dan bebas dari tanah atau kerikil; penggunaan topi, kuku tidak boleh panjang untuk karyawan penjamah makanan; pengendalian hama oleh pihak kedua yang setiap hari datang untuk menyemprotkan pembasmi serangga dan pemeriksaan jebakan tikus, serta pemeliharaan insect killer oleh engineering; dan pemilihan peralatan makan yang tidak rompal untuk menghindari pecahan bagian masuk ke dalam makanan.

\section{Menentukan Titik Kendali Kritis (Critical Control Point)}

Dalam SNI 01-4852-1998, titik kendali kritis mungkin terdapat lebih dari satu saat pengendalian bahaya dilakukan. Penentuan titik kendali kritis pada sistem HACCP dapat dibantu dengan menggunakan Pohon Keputusan yang dipublikasikan Codex, yang merupakan pendekatan pemikiran yang logis (masuk akal).

Berdasarkan hasil wawancara dan observasi yang dilakukan, penentuan titik kendali kritis telah dilakukan dengan benar dengan pendekatan yang sistematis menggunakan pohon keputusan (decision tree). Hyatt Regency Yogyakarta menentukan ada 9 (sembilan) CCP untuk keseluruhan proses dari penerimaan sampai pada penyajian makanan, yaitu:

1) CCP1: Receiving Chill Goods

2) CCP 2: Chill Storage

3) CCP 3: Sanitizing (Fruit\&Vegetables)

4) $\mathrm{CCP} 4$ : Cooking

5) CCP 5: Hot Holding

6) CCP 6: Cold Holding

7) CCP 7: Rapid Cooling

8) CCP 8: Reheating

9) CCP 9: Assembling / Platting.

Sebagian besar CCP berhubungan dengan suhu sebagai batas kritisnya kecuali untuk CCP 3 dan CCP 9. Sedangkan CCP yang diterapkan di main kitchen adalah $\mathrm{CCP} 2$, CCP 3, CCP 4, CCP 5, CCP 6, CCP 7, dan CCP 8. Penerapan CCP 1 dilakukan di Receiving dan untuk CCP 9 biasanya diterapkan di Banquet atau Outside Catering. Menetapkan Batas Kritis (Critical Limit) 
Dalam SNI 01-4852-1998, setiap titik kendali kritis (CCP) yang telah ditetapkan harus memiliki spesifikasi batas kritis untuk menetapkan batasan antara keadaan yang dapat diterima dan yang tidak dapat diterima. Batas kritis tersebut harus terpenuhi untuk menjamin bahwa CCP dapat dikendalikan dengan baik. Kriteria yang sering digunakan dalam pemantauan batas kritis biasanya meliputi suhu, waktu, tingkat kelembapan, $\mathrm{pH}, \mathrm{a}_{\mathrm{w}}$, serta parameter klorin, parameter visual, dan tekstur.

Berdasarkan hasil wawancara dan observasi yang telah dilakukan peneliti di Hyatt Regency Yogyakarta, pemantauan batas kritis telah dilakukan dengan baik. Penentuan spesifikasi batas kritis telah dilakukan untuk setiap titik kendali kritis yang berlaku di Hyatt Regency Yogyakarta. Kriteria batasan kritis yang ditetapkan antara lain meliputi suhu, waktu, dan $\mathrm{pH}$.

a. CCP 1: Receiving Chill Goods memiliki target limit (TL) $5^{\circ} \mathrm{C}$ dengan critical limit (CL) $8^{\circ} \mathrm{C}$ untuk chilled food, dan TL $\triangle 18^{\circ} \mathrm{C}$ dengan $\mathrm{CL} \quad \leq 2^{\circ} \mathrm{C}$ untuk frozen foodper Supplier's Specification

b. CCP 2: Chill Storage memiliki TL dan CL sama dengan CCP 1

c. CCP 3: Sanitizing memiliki TL pH $\leq$ 3 ppm dengan lama merendam selama $\geq 60$ detik

d. CCP 4: Cooking memiliki CL berbeda-beda tiap bahan makanannya, patty dengan tingkat kematangan rare harus mencapai suhu $\leq 40^{\circ} \mathrm{C}$, medium rare 40 $59^{\circ} \mathrm{C}$, medium $50-59^{\circ} \mathrm{C}$, medium well 60 $69^{\circ} \mathrm{C}$, dan titik kritis: well done $\succ 68^{\circ} \mathrm{C}$. Untuk poultry (solid\&ground) harus mencapai suhu $74^{\circ} \mathrm{C}$ selama 15 detik, stuffing $74^{\circ} \mathrm{C}$ selama 15 detik, ground / flaked meats $68^{\circ} \mathrm{C}$ selama 15 detik, beef/veal/lamb/other red meats $68^{\circ} \mathrm{C}$ selama 15 detik, Seafood $63^{\circ} \mathrm{C}$ selama 15 detik, Shell/Pasteurized Eggs/Dishes $63^{\circ} \mathrm{C}$ selama 15 detik, dan makanan lain $60^{\circ} \mathrm{C}$

e. CCP 5: Hot Holding memiliki TL $260^{\circ} \mathrm{C}$ dengan $\mathrm{CL} \geq 59^{\circ} \mathrm{C}$

f. CCP 6: Cold Holding memiliki TL $5^{\circ} \mathrm{C}$ dengan $\mathrm{CL} \quad 8^{\circ} \mathrm{C}$ g. CCP 7: Rapid Cooling memiliki TL $60^{\circ} \mathrm{C}$ ke $20^{\circ} \mathrm{C}$ dalam 2 (dua) jam dan $20^{\circ} \mathrm{C}$ ke $4^{\circ} \mathrm{C}$ dalam 2 (dua) jam berikutnya dengan $\mathrm{CL} 60^{\circ} \mathrm{C}$ ke $20^{\circ} \mathrm{C}$ dalam 2 (dua) jam dan $20^{\circ} \mathrm{C}$ ke $4^{\circ} \mathrm{C}$ dalam 4 (empat) jam berikutnya

h. CCP 8: Reheating memiliki TL $\geq 75^{\circ} \mathrm{C}$ dengan $\mathrm{CL} \geq 74^{\circ} \mathrm{C}$

i. CCP 9: Assembling/Platting memiliki TL maksimal 20 menit dalam suhu ruangan dengan CL 30 menit dalam suhu ruangan.

Batas kritis yang telah disusun sudah pernah divalidasi. Validasi yang dilakukan adalah dengan sampling product. Kegiatan validasi penting dilakukan untuk mengecek kembali apakah batas kritis yang ditetapkan benarbenar dapat menjamin bahwa bahan makanan aman untuk dikonsumsi.

\section{Menetapkan Suatu Sistem Pemantauan Pengendalian CCP}

Berdasarkan SNI 01-485201998, pemantauan merupakan pengukuran atau pengamatan terjadwal dari TKK yang dibandingkan terhadap batas kritisnya. Prosedur pemantauan harus dapat menemukan kehilangan kendali pada TKK. Data yang diperoleh dari pe,amtauan harus dinilai oleh orang yang diberi tugas, berpengetahuan dan berwenang untuk melaksanakan tindakan perbaikan yang diperlukan. Apabila pemantauan tidak bekesinambungan, maka jumlah atau frekuensi pemantauan harus cukup untuk menjamin agar TKK terkendali. Sebagian besar prosedur pemantauan untuk TKK perlu dilaksanakan dengan cepat, karena berhubungan dengan proses yang berjalan dan tidak tersedia waktu yang lama untuk malksanakan pengujian analitis. Semua catatan dan dokumen yang terkait dengan kegiatan pemantauan TKK harus ditanda tangani oleh orang yang melakukan pengamatan dan oleh petugas yang bertanggung jawab melakukan peninjauan kendali dalam perusahaan tersebut.

Berdasarkan hasil wawancara dan observasi yang dilakukan peneliti, Hyatt Regency Yogyakarta telah melakukan pemantauan setiap harinya dan pada setiap prosesnya. Hygiene Officer bertugas untuk memantau hasil pantauan yang dilakukan di 
masing-masing outletyang menerapkan CCP. Pemantauan hasil pantauan ini bertujuan agar apabila terjadi suatu penyimpangan dapa dilakukan tindakan koreksi segera.

Pemantauan di Receiving dilakukan untuk bahan makanan yang frozen maupun chilled setiap harinya setiap pengirimannya. Bahan makanan seperti meat, poultry, seafood, susu, dan jus harus diperiksa suhunya. Pemeriksaan suhu dilakukan pada bahan makanan dan juga cool box pada kendaraan yang mengirimkan. Pemeriksa suhu pada bahan makanan menggunakan termometer tusuk yang sudah disterilisasi terlebih dahulu, sedangkan untuk suhu cool box menggunakan termometer laser. Suhu bahan makanan tidak boleh melebihi critical limit. Apabila melebihi suhu, bahan makanan akan ditolak dan Receiving harus mengisi Rejection Food. Atau jika diterima harus dengan sepengatuhan commisarry dan disertai alasan mengapa bahan makanan tersebut diterima.Suhu yang sudah dicek kemudian dituliskan dalam Daily Food Delivery Report dan di akhir pemantauan harus menuliskan nama pada kolom 'checked by'. Setiap bahan makanan tersebut juga harus diberikan label Receive Date-nya.

Untuk pemantauan di Kemangi Kitchen sebagian besar berkaitan dengan suhu. Dimulai dari penyimpanan dingin, suhu chiller dipantau setiap pagi dan sore/malam antara suhu yang terpampang pada display dan suhu pada bahan makanan itu sendiri. Lalu pemantauan dilakukan untuk proses sanitasi pada buah dan sayuran. Perhatikan pH dan lama merendam buah dan sayuran. Selanjutnya pemantauan pada cooking temperature dan cooking temperature burger, hot holding, cold holding, rapid cooling, dan reheating. Pemantauan suhu selalu menggunakan termometer yang harus disanitasi sebelum ditusukkan pada makanan. Semua suhu tidak boleh melebihi critical limit. Beberapa dokumen yang digunakan dalam proses pemantauan di Kemangi Kitchen antara lain:

1) Cold Holding Unit Temperature Record untuk memantau suhu chiller/freezer (CCP 2)
2) Disinfecting Solution Record (Fruit\&Vegetables) untuk laporan pemantauan sanitasi buah dan sayuran (CCP 3)

3) Internal Cooking Temperature (Log for Burger) adalah record untuk memantau proses memasak patty burger (CCP 4)

4) Daily Temperature Record untuk catatan pemantauan pada setiap proses cooking (CCP 4), hot holding (CCP 5), cold holding (CCP 6) dan reheating (CCP 8)

5) Internal Cooling of Hot Temperature digunakan untuk catatan hasil pemantauan rapid cooling (CCP 7).

Setiap pencatatan hasil pemantauan yang dilakukan harus disertakan nama karyawan yang memeriksa.

Menetapkan Tindakan Perbaikan Yang Dilakukan Jika Hasil Pemantauan Menunjukkan Bahwa Suatu CCP Tidak Dalam Kendali

Berdasarkan pedoman penerapan HACCP dalam SNI 01-4852-1998 tindakan koreksi yang spesifik harus dikembangkan untuk setiap TKK dalam sistem HACCP agar dapat menangani penyimpangan yang terjadi.Tindakan-tindakan harus memastikan bahwa CCP telah berada di bawah kendali.

Hasil wawancara dan observasi menunjukkan bahwa tindakan koreksi yang dilakukan oleh Hyatt Regency Yogyakarta terbagi menjadi 2 (dua) macam, yaitu tindakan koreksi yang bersifat segera (corrective action) dan yang bersifat pencegahan penyimpangan (diviation control).

Pengiriman bahan makanan yang tidak sesuai dengan standar HACCP, akan Receiving koordinasikan dengan bagian commisarry, commis mau terima atau tidak. Kalau commis sudah melihat barang tersebut dalam kondisi baik, kemudian pertimbanganpertimbangan commis seperti apa yang membuat barang tersebut diterima, Receiving akan menerima barang tersebut dengan menuliskan reason mengapa barang tersebut diterima dan harus disertai paraf commis. Barang yang ditolak pada saat penerimaan harus dicatat dalam sebuah report sendiri. Reason mengapa barang tersebut ditolak, 
jenis barangnya, serta vendor yang mengirimkan. Untuk ke depannya Receivingmenginformasikan kepada vendor agar mendatangkan barang yang sesuai dengan standar HACCP yang telah ditetapkan.

Tindakan perbaikan yang dilakukan di main kitchen apabila pada suatu CCP tidak mampu mencapai critical limitadalah:

1) Apabila dalam penerapan CCP 2: Chill Storage suhu chiller/freezer tidak mencapai critical limitmaka perlu mengambil tindakan perbaikan. Pertama adalah memindahkan makanan ke chiller/freezer alternatif dengan suhu tidak melebihi CL, selanjutnya informasikan langsung ke bagian Engineering untuk dilakukan perbaikan atau dengan menggunakan work order.

2) Tindakan koreksi yang dilakukan apabila CCP 3: Sanitizing melebihi CL adalah dengan mengubah perbandingan air dengan cairan sanitasi dan melanjutkan perendaman sampai waktu yang ditetapkan.

3) Jika pada proses CCP 4: Cooking suhu tidak mencapai CL maka proses memasak harus diteruskan sampai tercapai suhu sesuai CL, tingkatkan panas untuk memask, selanjutnya maintenance pada alat-alat masak.

4) Apabila pada CCP 5: Hot Holding suhu makanan hanya $59^{\circ} \mathrm{C}$ selama 2 (dua) jam, makanan harus dibuang dan informasikan kepada Engineering untuk melakukan perbaikan

5) Tindakan perbaikan pada CCP 6: Cold Holding jika suhu tak mencapai CL adalah dengan mengurangi masa penyimpanan selama 2 jam saat didisplay, lalu informasikan ke Engineering untuk segera diperbaiki.

6) Apabila CCP 7: Rapid Cooling tidak mencapai CL maka makanan akan dibuang.

7) Tindakan perbaikan yag dilakukan apabila CCP 8: Reheating tak mencapai suhu CL, lakukan seperti pada tindakan perbaikan proses cooking.
8) Yang terakhir untuk tindakan perbaikan CCP 9: Assembling/Platting pertama dengan mengecek suhu internal makanan, jika suhu $>8^{\circ} \mathrm{C}$ atau $<60^{\circ} \mathrm{C}$, buang makanan tetapi apabila suhu internal makanan $88^{\circ} \mathrm{C}$ atau $\succ 60^{\circ} \mathrm{C}$, segera pindahkan ke pendingin atau penghangat makanan.

Sebagai langkah pencegahan penyimpangan yang terjadi, Hyatt Regency Yogyakarta melakukan maintenance terhadap chiller/freezer secara berkala, pengelolaan air agar aman dikonsumsi, pengendalian hama, serta pengolahan limbah pada kitchen.

\section{Menetapkan Prosedur Verifikasi Untuk Memastikan Bahwa Sistem HACCP Bekerja Secara Efektif}

Dalam SNI 01-4852-1998 metode audit dan verifikasi, prosedur dan pengujian, termasuk pengambilan contoh secara acak dan analisa, dapat dipergunakan untuk menentukan apakah sistem HACCP bekerja secara benar. Frekuensi verifikasi harus cukup untuk menkonfirmasi bahwa sistem HACCP bekerja dengan efektif.

Berdasarkan hasil wawancara dan observasi yang dilakukan peneliti, Hyatt Regency Yogyakarta telah melaksanakan prosedur verifikasi dengan baik. Kegiatan verifikasi yang dilakukan Hyatt Regency Yogyakarta antara lain: peninjauan kembali penerapan HACCP dan catatannya pada setiap outlet yang dilakukan oleh Hygiene Officer setiap pagi dan sore setiap harinya, sampling random produk yang dilakukan setiap bulan, melakukan audit ke supplier per 6 (enam) bulan sekali, mengadakan audit internal per 3 (tiga) bulan sekali maupun mengadakan audit eksternal untuk FSMS setiap 6 (enam) bulan sekali dan audit eksternal untuk HACCP setiap tahun sekali, serta mengalibrasi termometer tusuk 2 (dua) kali dalam sebulan dan setahun sekali untuk pengkalibrasian alat yang dilakukan di badan metrologi.

Menetapkan Dokumentasi Mengenai Seluruh Prosedur Dan Rekaman Yang Seuai Dengan Prinsip-Prinsip Dan Penerapannya 
Dalam SNI 01-4852-1998, pencatatan dan pembuktian yang efisien serta akurat adalah penting dalam penerapan sistem HACCP. Prosedur harus didokumentasikan. Dokumentasi dan pencatatan harus cukup memadai sesuai sifat dan besarnya operasi. Pencatatan mencakup kegiatan pemantauan $\mathrm{CCP}$, penyimpangan dan tindakan perbaikan yang terkait, perubahan pada sistem HACCP.

Berdasarkan wawancara dan observasi, dokumentasi HACCP di Hyatt Regency Yogyakarta sudah lengkap mulai dari analisis risiko bahaya pada setiap menu, standard product specification, pengumpulan setiap hasil pemantauan di outlet yang ditelah diverifikasi oleh orang yang bertanggung jawab atas masing-masing outlet, HACCP Plan untuk Hot\&Cold Process yang telah diverifikasi oleh Chef dan Dir. of FB, sturktur organisasi Tim HACCP beserta job description-nya masing-masing, serta dokumentasi setiap pelaksanaan internal audit maupun

eksternal audit.

Berdasarkan hasil analisis, ketujuh prinsip yang diterapkan di main kitchen Hyatt Regency Yogyakarta telah dilaksanakan dengan baik sesuai dengan standar SNI 01-4852-1998 dimana bahaya dapat dikontrol, dieliminasi, dan dikurangi secara efektif dan efisien. Sehingga dapat dikatakan bahwa seluruh kegiatan pengolahan makanan di main kitchen Hyatt Regency Yogyakarta telah mampu menjamin keman

\section{KESIMPULAN}

Bagan alir yang disusun telah mencakup dari semua tahapan mulai dari penerimaan bahan makanan dari vendor, sampai pada proses penyajian makanan pada tamu. Hyatt Regency Yogyakarta memiliki 2 (dua) bagan alir dalam HACCP Plan yaitu Hot Process dan Cold Process.

Prinsip pertama pada HACCP yaitu analisis bahaya telah dilakukan dengan baik dan telah mencakup 3 (tiga) kriteria bahaya yaitu bahaya biologi, kimia, dan fisik dan juga telah menentukan tingkatan bahaya dari bahan makanan yang digunakan.

Penerapan Prinsip-Prinsip HACCP di main kitchen Hyatt Regency Yogyakarta sebagai berikut :

1) Analisis Bahaya telah dilakukan pada setiap proses pengolahan makanan. Identifikasi bahaya yang dilakukan mencakup bahaya biologi, kimia dan fisik yang mungkin timbul. Identifikasi bahaya dilakukan menggunakan HACCP Plan (diagram alir).

2) Penetapan Critical Control Point (Titik Kendali Kritis) telah dilakukan dengan benar dan telah ditentukan dengan pendekatan yang sistematis dengan menggunakan pohon keputusan (decision tree). Penentuan CCP di Hyatt Regency Yogyakarta telah sesuai dengan tujuan HACCP.

3) Batas kritis (Critical Limit) yang ditentukan sudah memisahkan kondisi yang dapat diterima dan kondisi yang tidak aman.

4) Penetapan prosedur pamantauan atau monitoring telah dilakukan secara sistematis pada titik dimana bahaya yang telah diidentifikasi dapat dikontrol (titik kendali kritis).

5) Penetapan tindakan koreksi telah ditetapkan dengan baik pada setiap CCP apabila tidak dapat mencapai batas kritis yang telah ditentukan.

6) Penetapan Verifikasi sudah dilakukan dengan baik untuk mengukur sejauh mana program HACCP yang disusun dapat menjamin makanan bebas dari bahaya dan aman untuk dikonsumsi.

7) Penetapan Dokumentasi sudah dilakukan untuk seluruh aspek terkait. Semua dokumen sudah lengkap.

Berdasarkan hasil wawancara dan observasi yang dilakukan oleh peneliti maka dapat ditarik kesimpulan bahwa ketujuh prinsip HACCP telah diterapkan dengan baik sesuai dengan standar SNI 01-4852-1998 dimana bahaya dapat dikontrol, dieliminasi, dan dikurangi secara efektif dan efisien pada titik-titik yang mungkin menimbulkan bahaya. Sehingga dapat dikatakan bahwa pengolahan makanan di main kitchen Hyatt 
Regency Yogyakarta telah menjamin Nazir.

(2011). kemanan pangan bagi tamu.

Berdasarkan kesimpulan yang diperoleh dapat dikembangkan beberapa saran bagi pihak-pihak yang berkaitan dalam penelitian ini. Adapun saran yang mungkin dapat menjadi bahan pertimbangan adalah sebagai berikut:

1) Tetap menjaga konsistensi dalam penerapan prinsip-prinsip HACCP di Hyatt Regency Yogyakarta.

2) Untuk cook agar lebih peduli untuk menjaga cleanlines area kerjanya masingmasing.

3) Cook diharapkan ikut serta dalam menjaga chiller/freezer agar kerusakan tidak sering terjadi.

4) Pembaharuan peralatan yang bersentuhan langsung dengan makanan.

5) Diadakannya pelatihan tentang ISO sebagai persiapan menuju ISO setelah sertifikasi HACCP yang kedua.

6) Untuk STP AMPTA agar menetapkan Hazard Analysis Critical Control Point (HACCP) sebagai mata kuliah yang menggantikan mata kuliah Hygiene \& Sanitasi.

\section{REFERENSI}

Arikunto, Suharsimi. (2006). Prosedur Penelitian: Suatu Pendekatan Praktek. Jakarta: PT. Rineka Cipta.

Dewanti, Ratih dan Hariyadi. (2013). HACCP: Pendekatan Sistematik Pengendalian Keamanan Pangan. Jakarta: Dian Rakyat.

Hermawan, H., Brahmanto, E \& Faizal H. (2018). Pengatar Manajemen Hospitality. Pekalongan: Penerbit NEM.

Kuncoro, Mudrajad. (2003). Metode Riset untuk Bisnis \& Ekonomi. Jakarta: Erlangga.

27 Januari 2017 